\title{
ДО 80-РІЧЧЯ ВІД ДНЯ НАРОДЖЕННЯ АГНЕТИ ІВАНІВНИ МОСТЮК
}

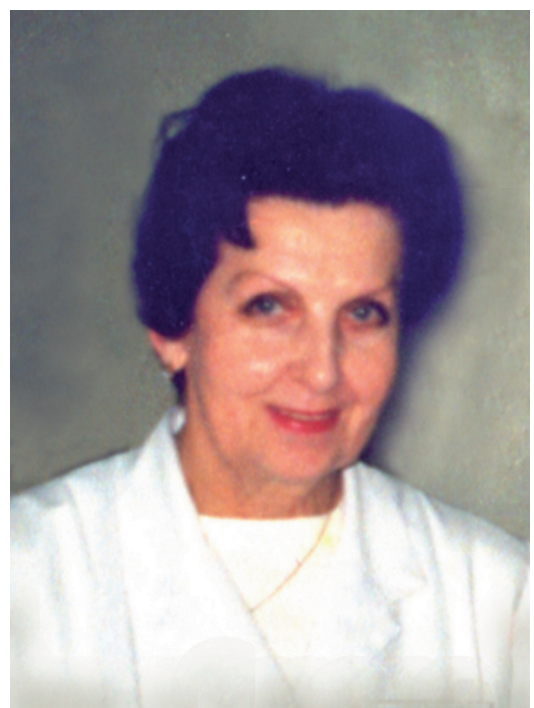

13 березня виповнилось би 80 років видатному вченому, педагогу, клініцисту-інфекціоністу, доктору медичних наук, професору Львівського національного медичного університету ім. Данила Галицького, академіку АН вищої школи України Агнеті Іванівні Мостюк.

Агнета Іванівна народилась в м. Ужгороді Закарпатської області. Після закінчення школи із золотою медаллю здобувала лікарську освіту з 1953 по 1959 рр. в Львівському державному медичному інституті. У 1959-1963 рр. працювала лікарем-ординатором дитячого відділення Львівської залізниці. Успішно закінчила аспірантуру при кафредрі інсрекційних хвороб лдМІ (1963-1966 рр.), працювала лікарем-ординатором, завідувачем дитячого відділення Інфекційної клінічної лікарні м. Львова (1966-70рр.), асистентом (1970-78рр.), доцентом кафедри інфекційних хвороб лДМІ (1978-86 рр.).

В 1967 р. Агнета Іванівна захистила кандидатську дисертацію «Проникність капілярів і білковий склад сироватки крові при інфекційному гепатиті у дітей» (під керівництвом дой. Б.М. Котляренка), у 1985 р. - докторську дисертацію «Вірусний гепатит у дітей першого року життя» (наук. консультант М.Б. Тітов). У цих роботах Агнета Іванівна описала клінічні фрорми, наслідки та лікувальну тактику при ВГВ, провела глибокий аналіз причин цієї хвороби у дітей першого року життя, зокрема, необґрунтованих переливань крові та її препаратів.
Згідно з наказом ректора лдМІ від 28.08.1986 р., було створено курс дитячих інсекційних хвороб при кафредрі фракультетської та шпитальної педіатрії. Агнета Іванівна очолила курс, а з 1989 р. і кафедру дитячих інсрекційних хвороб. Найважливішим у становленні новоствореної кафредри вважались фрормування належного професійного рівня викладацького складу, організація умов для науководослідницької роботи, забезпечення надання кваліфікованої лікувально-консультативної допомоги базовому стаціонару, медичним закладам Львова та області, й, за потреби, інших областей України.

До педагогічної роботи були залучені висококваліфріковані лікарі-інфекціоністи з досвідом практичної роботи, високим рівнем базової підготовки та навичками проведення наукових досліджень.

Вихідний науковий напрямок кафедри базувався на вивченні механізмів корекції розладів гомеостазу і модуляції імунної відповіді при застосуванні ентеросорбентів у комплексному лікуванні інфекційних хвороб у дітей. У 1993-1995 рр. на кафедрі, поряд з плановою, виконувалась наукова робота на тему: «Розробка нових методів лікування гострих кишкових інфекцій і вірусних гепатитів композитними детоксикаційно-корекційними препаратами ентерального застосування», яка, відповідно до результатів галузевого конкурсу, отримала пріоритетне фрінансування МОЗ України. При виконанні означеної наукової тематики кафедра дитячих інсрекційних хвороб співпрацювала з IHститутом хімії поверхні АН України, виконуючи відповідно до контрактів певні розділи роботи щодо розробки нових ентеросорбентів.

У зв'язку з надзвичайною епідемічною ситуацією з дисртерії, що склалася в Україні у 90-ті роки, модисріковано основний напрямок наукових досліджень кафедри. Упродовж 1994-1995 рр. кафедра співпрацювала з НДІ епідеміології та гігієни, виконуючи певні розділи науково-дослідної роботи на тему: «Вивчити особливості циркуляції збудника в осередках дифтерії та вдосконалити заходи по санації носіїв 3 метою ліквідації вогнища».

У пошуках оптимальних варіантів лікування хворих на дистерію дітей увагу було зосереджено на можливостях корекції розладів локального та системного гомеостазу за допомогою ентеросорбентів. Паралельно розпочато проведення експериментальних досліджень у мурчаків 
для 3'ясування інтимних механізмів пошкоджувальної дії дифтерійного екзотоксину за даними змін ультраструктури клітин уражених органів, можливостей нівелювання їх специфічним анатоксином, розроблення оптимальних варіантів лікування з конкретизацією дозування препарату. Вивчались водночас наслідки впливу на організм парентерально введених гетерогенних білків.

Під керівництвом Агнети Іванівни на кафедрі виконано і захищено 10 докторських та кандидатських дисертацій.

Агнета Іванівна була автором понад 200 наукових праць і науково-методичних посібників, співавтором підручника «Дитячі хвороби», який вперше в незалежній Україні було видано українською мовою; розділів інфекційних хвороб в «Орфографрічному словнику українських медичних термінів», «Українсько-латинському тлумачному словнику», керівництва для лікарів «Медицина дитинства» за ред. профр. П.С. Мощича, журналі «Педіатрія» та численних тематичних порадників і методичних рекомендацій.

Серед особливо важливих праць Агнети Іванівни є монограсрія «Дисртерія», в якій узагальнені сучасні досягнення інфектології щодо проблеми дистерії на підставі аналізу великої кількості відомостей літератури та висвітлення власних поглядів стосовно того чи іншого дискусійного питання, 3 аргументацією результатів власних спостережень і цілеспрямовано проведених досліджень. Значне місце приділено подібним до дистерії захворюванням, які супроводжуються ураженням ротоглотки, створюють труднощі ранньої та диференційної діагностики. Видана у 1996 р., ця монографрія залишається настільною книгою для інсекціоністів, епідеміологів, педіатрів, сімейних лікарів і студентів старших курсів медичних вузів.
3 ініціативи Агнети Іванівни на касредрі організовано післядипломне навчання з інфекційних хвороб дитячого віку для лікарів-інтернів: дитячих інфрекціоністів, педіатрів, неонатологів, лікарів загальної практики та сімейної медицини, медицини невідкладних станів, отоларингологів; курси первинної спеціалізації та передатестаційні цикли підготовки лікарів з дитячих інфекційних хвороб: курси тематичного удосконалення «Актуальні питання дитячих інфрекційних хвороб».

Агнета Іванівна Мостюк була висококваліфікованим інфекціоністом, досвідченим високоерудованим викладачем, чудовим лектором. Ведення нею клінічних обходів, конференцій, рецензування історій хвороб, виступи на з"їздах були високою школою медичного мистецтва. Вона уміла зацікавити слухачів, чітко, доступно, образно викладала матеріал.

Агнеті Іванівні були властиві доброзичливість, чуйність, уважне ставлення до співробітників, студентів та пацієнтів, вимогливість, дисциплінованість, велике почуття відповідальності за доручену справу. Цим якостям вона навчала своїх численних учнів.

Одночасно Агнета Іванівна була турботливою, уважною та люблячою матір'ю, дружиною, бабусею та прабабусею, вона започаткувала лікарську династію, ії̈ справу успішно продовжують дочка та онуки.

17 грудня 2015 р. перестало битись серце Агнети Іванівни. Пам'ять про цю напрочуд мудру, високо порядну, неординарну людину назавжди залишиться в серцях вдячних учнів, колег і пацієнтів.

Колектив Львівського національного медичного університету ім. Д. Галицького президія Всеукраїнської асоціації інфрекціоністів. 